\title{
Plenty of land, land of plenty: the agrarian output of Portugal (I3II-20)
}

\author{
A N T Ó N I O HENR I Q U E S \\ Faculdade de Economia, Universidade do Porto, 420o-464 Porto, Portugal, ahenriques@fep.up.pt \\ Instituto de Ciências Sociais, Universidade de Lisboa, Lisbon, Portugal
}

\begin{abstract}
This article presents a benchmark for Portuguese agrarian output for the I3II-20 decade. This benchmark is built from the supply side using the value of church tithes combined with contemporary parish accounts. Two main findings emerge: first, per capita agrarian output was similar in the recently conquered South and the North, hinting that internal migration after the Reconquista led to the equalization of marginal product across the country; second, that Portuguese real per capita agrarian output was above subsistence and higher than that of contemporary England and Wales. This result, which is robust to the assumptions used, confirms that by 1320 Portugal was a "frontier economy" with a high land/labor ratio and a high per capita output. This seems to reinforce the Malthusian theory that the amount of land per person was key in determining living standards. The article discusses the implication of these results for the inequality among nations.
\end{abstract}

\section{Introduction}

Inequality between countries has deep roots. Well before Europe surged ahead of the rest of the world, there was a subtle but steady divergence within the continent, as England and the Netherlands grew faster than their neighbors. This "Little" or "First Divergence" started well before the period of rapid technological advance that we know as Industrial Revolution. Recent reconstructions of national accounts from the late thirteenth century onward confirm that the First Divergence might have started as soon as the fourteenth century (Pamuk 2007). In fact, whereas Spain (Álvarez-Nogal and Prados de la Escosura 20I3) and Italy (Malanima 2010) were at some point caught by growth stagnation and decay of living standards, England and the Netherlands exhibit a nearly continuous growth trend (Zanden and Leeuwen 20II; Broadberry et al. 20I2). These results have the effect of moving back the debate about the forces that underlie economic inequality between countries to 1300 rather than 1800 or 1500 .

By 1300 , however, after centuries of demographic and economic growth, European economies appear to have been caged inside a tight Malthusian regime. This means that output increases translate as higher fertility and that, in the absence of technological advance, population growth leads to diminishing returns of labor as land becomes increasingly scarce. Thus, demographic growth above a certain standard of living triggers "positive checks" (higher mortality induced by declining living conditions) or else preventive checks (fertility restrictions). These forces contrive to keep real per capita output constant in the long run. While they faded away along with the Little Divergence (Nicolini 2007; Crafts and Mills 2009), available evidence indicates that by $\mathrm{I} 300$ mortality still functioned as a positive check, i.e., that it responded to real wages (Kelly and Ó Gráda 20I3, p. I2). 
There was, nonetheless, hope for fourteenth-century Europe. Voigtländer and Voth (2013) indicate that the Malthusian cage was unlocked by a specifically European mortality regime marked by "[high-mortality] great cities, pestilence, and war" (Voigtländer and Voth 2013, p. Io). This is compatible with recent research on national accounts. Where the Malthusian trap was more severe, per capita output and real wages appear relieved by the Black Death (Malanima 20IO; Broadberry et al. 20I2). The alleged positive impacts of war were also confirmed, albeit less directly by Álvarez-Nogal and Prados de la Escosura (2013, figure 7), who argue that the conquest of the Muslim-held half of the Peninsula contributed to a high-mark of real per capita output that would not be bettered until the nineteenth century. The Reconquista turned present-day Spain into a "frontier economy", a country with a favorable land/labor ratio in a period when most European countries suffered from decreasing marginal returns.

In short, in a Malthusian context, it takes plenty of land to be a land of plenty. This article provides further evidence for this by estimating a benchmark for Portuguese agricultural output for the decade I3I I-20. The case of Portugal, whose Reconquista ended in I249, will test whether favorable land/labor ratios allowed indeed for better living conditions.

The second intended contribution is enlarging the number of countries that can be summoned to this debate. Assessing living standards and inequality between nations hinges on accurate and comparable estimates of per capita output for different countries. These are difficult to construct for earlier periods due to the scarcity of data and to the methodological challenges earlier sources create. Presently, not only the discussion is limited to a few countries but also it is mostly based on indirect, demand-side reconstructions, which pose overwhelming index problems and rely mainly on real wages. Research is starting to take the alternative path of reconstructing national accounts from the output side. This was attempted for England from 1270 to I 870 by Broadberry et al. (2012), who found evidence of per capita growth since the thirteenth century, contradicting the pessimism of earlier research based upon product and factor prices.

Finally, the present benchmark represents a first step toward quantifying pre-I 500 Portuguese economy. The views on the country's long-term development have largely adopted the pessimistic thesis drawn inter alia by the influential medievalist Oliveira Marques. For this school of thought, structural problems like inadequate natural resources, peripheral position, poor communications, and uneven urban development meant that agriculture struggled to provide the necessary products. The Great Plague offered only a temporary respite to a poorly fed population living in a demographically saturated country. Post-Plague welfare gains would prove temporary, as the structural problems subsided and condemned Portugal to be on the wrong side of the European divergence (Marques 1978, 1987).

The article is structured as follows. Section 2 will provide an overview of Portuguese agriculture and institutions $c$. I300. Section 3 will present the available data and estimation methods used. Section 4 will show the implications of the estimates in a comparative context, while section 5 will discuss the robustness of the data and its compatibility with other evidence on living standards. Finally, Section 6 will resume the debate presented in this introduction and conclude.

\section{Historical background}

By I300, contrary to most European economies where natural resources were stretched by centuries of population growth (Campbell 2008; Clark, 20I0, table I8; Malanima 2009), Portugal could still be defined as a "frontier economy", a labor-scarce rather than a land-scarce 
agrarian economy. The capture of the Algarve by King Afonso III in I249 culminated a swift advance through the southern plains that led to a 35 percent increase in the area of the kingdom in about three decades (I2I7-49). As a century (II47-I249) of nearly continuous war had driven a large share of the Muslim population away, conquered lands were thinly settled, when not abandoned. Large-scale migration to Muslim-held territory in Spain or North Africa followed the Reconquista and the Moors who remained under Christian rule were confined to one-third or one-fifth of arable land (Fernandes 2000; Barros 2007).

With the former occupants largely gone or dispossessed, the south offered a large space to Portuguese settlers. Given the absence of effective feudal restrictions on labor mobility, northsouth migration ensued (Barbosa I992, p. I69; Viana 2007). The settlement of the conquered lands was gradual rather than immediate as potential migrants had other options. In older lands, there was still scope for assarts and clearances in the first half of the fourteenth century. The crown waived privileges and promised self-government in order to attract new settlers to the string of fortified towns founded along the border with Castile. Thus, there was an eastward, as well as a southward, flow from the densely populated lands in the Northwest to the frontier. Both frontiers proved spacious enough to accommodate Portuguese and even foreign settlers. In I340s, there was still room to found villages near the best wheat-growing lands (Viana 2007). In the I320s, settlement of the new areas was still underway, especially in the south. In 1329, nearly a century after its conquest, the southwest could still be described as "a new land, with much room for improvement" (TT, Ordem de Santiago/Convento de Palmela, DR, I, 25).

In a frontier economy, the availability of land is correlative to the scarcity of labor. This was the case of Portugal. As mentioned, labor flowed without much hindrance from northern Portugal to the east and south. Labor freedom opened up the possibility of equaling marginal product across the old and new lands. This appears confirmed by the proximity of annual wages in the densely settled northwest in I253 (Marques I97I) and in a southern newly colonized village in I27I (Saraiva I997). Royal laws pressing down wages in I2II, I253, and I340 confirm at the manpower difficulties facing landowners well before the Plague.

The migrants from the north benefitted from large-scale distributions of arable plots in the new lands. This redistribution gave way to a new system of property rights and to municipal institutions with a strong element of self-rule (Esteves 2003). The municipalities founded in the conquered lands assigned unoccupied land to the incoming settlers, a process that continued up to the mid-fourteenth century (Rau I982). Municipal law, set in royal charters, protected individual property rights and regulated the use of the commons. While subject to royal (or even seigniorial) authority and taxation, such towns had a measure of self-rule and offered an alternative to more forceful seigniorial jurisdiction (Mattoso 200I). Thus, to a large extent, institutions appear little influenced by feudal limitations. For instance, the customs of Santarém, which expressly forbade seigniorial monopolies on mills, were applied to the entire kingdom by Afonso III (I248-79) (Gonçalves I989, p. I68).

The ample availability of land for settlers went hand-in-hand with relatively low levels of urbanization. In this respect, the Portuguese contrasted with the Spanish one. The Islamic urban network in Portuguese-held territory was peripheral: neither Lisbon nor Santarém had been Muslim capitals. Beja and Évora and the ports of the Algarve (Silves, Faro, and Tavira) had at some point been capitals or city-states. All these were considerably smaller than the main Muslim cities such as Córdoba, Seville, Toledo, Valencia, or Zaragoza. The Reconquista further disrupted the links with these centers. As Portuguese trade veered toward the Atlantic, commerce with Castile was severed. These differences show up in Portuguese and Spanish urbanization rates c. I300, with the latter being one of the highest in Europe and the former below average (Malanima 
2009, p. 245). Most of the one hundred or so municipal towns (vilas) were essentially administrative and military. These municipalities erected barriers to trade and show few signs of economic specialization. Thus, on the whole, Portuguese urban networks offered few demand-side stimuli for its agriculture. This was compounded by the limited importance of the wage economy, in a country where access to land either through ownership or lease knew few limitations.

\section{Data}

It is possible to reconstruct Portuguese per capita agrarian output for I I I I - 20 by combining data from different sources. For the sake of clarity, Section 3 was divided into four parts: Subsection 3.I presents the relevant sources, Subsection 3.2 estimates tithe revenues from this evidence, and the two remaining subsections convert tithes revenues in output (Subsection 3.3) and per capita output (Subsection 3.4).

\section{I Sources}

Total tithe revenues for I3II-20 can be obtained by combining the taxatio, an extraordinary source that contains the assessment of the revenues of all Portuguese parishes in 1320 , with a few roughly contemporary tithe accounts at parish level. The taxatio was compiled on demand of Pope John XXII, who had agreed in I3I9 to grant to the King of Portugal a tenth of all the ecclesiastical benefices within the kingdom. The assessment (taxatio) of the benefices was conducted by an English prelate along with two native clergymen, who valued the revenues of the 2,768 ecclesiastical benefices of the realm, including 2,423 parish churches (figure I). The troika was careful enough to avoid double-counting by distinguishing the different recipients of each benefice and was instructed to lighten the burden of poorer benefices (Boissellier 2012 , p. 125). Conveniently, all assessments are expressed in money of account (Portuguese libras) and stand for the average revenue of the ten preceding years, a very considerate gesture toward future historians. This source was recently re-edited by Boissellier (20I2).

In contrast, accounts indicating the tithes collected at parish level are very hard to find. Searches in archives and in published sources only rendered accounts for ten parishes in the period 1309-27. Six accounts relate to churches belonging to military orders and, accordingly, record only the patronal share of the tithes. Of these, five were found inside a later copy of the accounts of the extinct Knights Templar (see figure 2), while the sixth source was recently identified (Oliveira 20I2). An enquiry on the production of the lands disputed by rival parish churches in Torres Vedras in 1309 provides the remaining four accounts. This enquiry was published by Johnson (1970) and its data were worked by Lopes (1966). Unlike the other accounts, this one indicates the total, i.e., pre-tithe, output. The data from these sources are systematized at table AI, with all payments in kind converted to Portuguese libras, using I3II-20 prices.

\subsection{From taxatio assessments to the tithe}

Essentially, the present reconstruction of the total tithe in the kingdom combines the variation of parish assessments in the kingdom (given in the taxatio) with the volumes provided by contemporary tithe parish accounts. This method is based upon three assumptions about ecclesiastical taxation in fourteenth-century Portugal. 


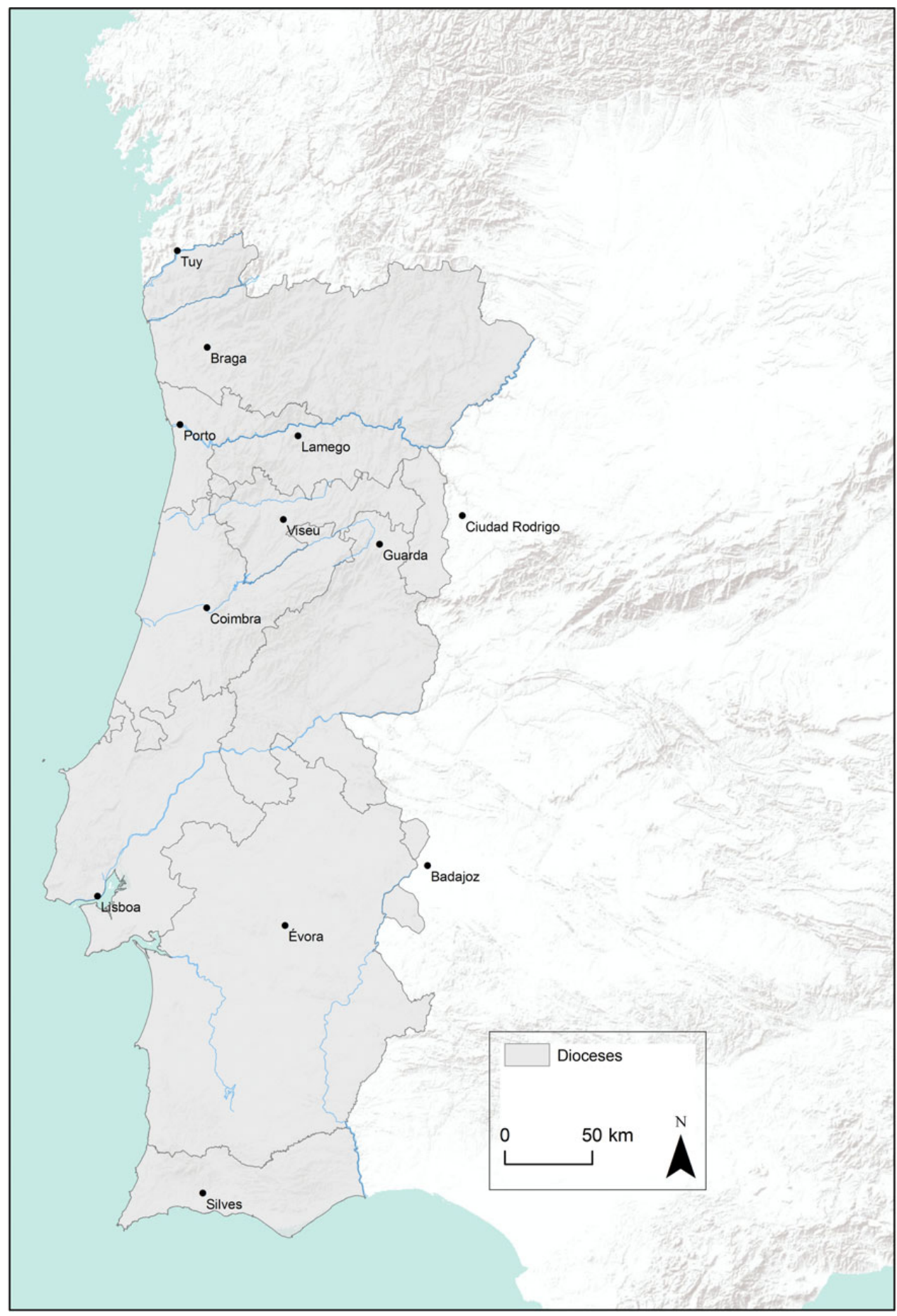

Figure I. The dioceses in Portugal, c. 1320 (approx. limits). Cartography by Cláudia Viana. 
The first assumption is that tithes provided the bulk of parish revenues, like elsewhere in Europe (Viader 20I0, pp. 17-8). Thus, the variation within the taxatio reflects the variation in the tithe collected rather than rents or other patrimonial revenues.

The second is that the assessment of each parish shown in the taxatio is lower than one-third of the actual tithes collected. In fact, parish clergy only retained a share, typically one-third, of the gross tithe in order to maintain their livelihood, as prescribed by cannon law (Viterbo I966, II, p. I7I), and pay the taxes and fees owed to the bishop (Costa [1959] I997-2000; Vilar 2007). The bishop or chapter collected yet another third, while the remaining one was assigned to the church patron who, in theory, had to pay for the cult expenses and conservation works (Vilar I999; Almeida I910-28). Thus, parish benefices obtained one-third of the tithes, at best.

The final assumption is that the assessments of the parishes followed a progressive rationale. This is clearly stated in the papal instructions to the troika, who was urged to assess only net revenue (i.e., discounting episcopal taxes that vicars were liable to) and to proceed with "just and equal moderation" in order not to overload poorer benefices. This made sense, as expenses with the buildings, the cult or the sustenance of the vicar did not decrease according to the size or wealth of the parish. Moreover, the marginal utility of the revenues was greater for the holders of poorer benefices.

The comparison of the values obtained from parish tithe accounts with those taken from the taxatio (see table AI) fully confirms these observations.

First, parish accounts show that the tithe dwarfed the remaining sources of income (land rents, alms, and fines). The strong correlation between the tithe collected in these parishes and their taxatio assessment $\left(r^{2}=0.9668\right)$ confirms that the variation of parish assessments hinges upon the variation of the tithe.

Second, as anticipated, tithe revenues are a multiple of the parish evaluations in 1320 . In fact, this multiple is considerably larger than three. Tomar is the proverbial exception that proves the rule because, as a nullius diocesis territory, it did not share its tithe with the local bishop.

Finally, the accounts attest that the assessments of wealthier parish benefices was in fact more severe than those of the poorer ones, as stated by the papal instructions. Seemingly, the concern with poor parishes took the form of progressive assessment rates. This should not come as a surprise given that concepts like net/gross, marginal utility, and even poverty threshold (estimated at 80 libras by the archbishop of Braga in I296; Repas 2003, doc. I49) impregnated ecclesiastical taxation.

Given that the troika under-assessed poorer parishes and that benefices were a fraction of the tithe, the tithe was more than three times the taxatio. In order to convert the values of the taxatio into the total tithe, we inferred a functional relationship between the assessments $(x)$ and the rates at which they were taxed (y) in our sample (table AI). Using the best fit for this regression, we obtain a curve that roughly $\left(r^{2}=0.6738\right)$ captures the relationship between these two variables. With this regression we can predict the annual total tithe by adding up the predicted values of all the 2423 parish assessments. Thus, the predicted value of the annual tithe collected in Portugal during the I3I I-20 period is I.5 million Portuguese libras.

\subsection{From the tithe to output}

It is realistic to use tithe revenues as a basis for estimating agrarian output in fourteenth-century Portugal. In fact, the underlying rationale of the tithe was that all fruits of nature ought to be tithed in order to acknowledge that nature was lent to man by God (Henriques 2013). Thus, tithes tapped essentially outputs (e.g., animal offspring) and left out inputs (e.g., breeding animals). As ordered by the archbishop of Braga in 1304, tithes ought to be paid gross, 
"without allowing for expenses" (Viterbo I966, pp. 247-8). There was no exemption for selfconsumption or rent and both the market-oriented products (grain, livestock, wine, and olive oil) and the goods produced and consumed within the household were tithed. The centralizing efforts of the bishops led to the adoption of a common set of rules regarding the collection, management, and division of tithe revenues throughout the realm, including making royal, church, and noble lands liable to the tithe (Vilar I999). Muslim population was an exception insofar as it paid the tithe to the king rather than to the church (Barros 2007).

However, the simple ten-fold multiplication of the total tithe does not amount to either net or gross agrarian product. Commodities were tithed, i.e., divided by ten, at different stages of their production process. Grain was tithed gross of seeds and, hence, tithe revenues on the arable sector tapped more than one-tenth of net output. The same can be said of the sectors in which the tithe fell on finished products, i.e., on wine and olive oil, rather than on grapes and olives. In contrast, the tithe paid by the pastoral sector was considerably less than one-tenth of the output. In fact, this tax fell on the output of the livestock, that it to say, offspring, dairy products and wool. This criterion left out the lion's share of this sector: animals slaughtered for meat.

The shares of net output taken by the tithe in the main agrarian commodities can be quantified (Henriques 2013, p. 86). The tithe on grain tapped I2.5 percent of the value of arable output. Tithes on wine and olive oil were less severe, as they stood for I0.3 and II.I percent, respectively. Finally, tithes on livestock took only modest shares of the production (2.7 percent for bovines, 3.4 percent for swine, 4.5 percent for sheep, and 5.5 percent for sheep). By combining these coefficients with the shares of these sectors in the agrarian product (see table $\mathrm{A}_{3}$ ), we find that tithes tapped 10.75 times the agrarian output. Hence, the coefficient required to obtain the agrarian output from the total tithe revenues is 9.3 (the inverse of I0.75) rather than IO. This means that Portuguese agrarian yearly output in I3I I-20 amounted to some I4 million libras.

\section{4 From output to per capita output}

Total net output becomes meaningful when divided by population. The most consistent approach to this variable remains that by Mattoso, who proposed a total population of 700,000 souls for I290. His method was to apply to the whole kingdom the ratio between notaries public and the demographic density in a vast area for which there was reasonable demographic information (Mattoso 200I, pp. I4-8). Mattoso admitted that his figure was "almost certainly too low". In fact, the implied population density $\left(7.8 / \mathrm{km}^{2} ; 4.8 / \mathrm{sq}\right.$. mile) is about half that for contemporary Scotland as estimated by Campbell (2008, p. 927). However, Mattoso's method returns a population slightly over one million if corrected using new research on the actual numbers and distribution of all the notaries public (Sá Nogueira 2008) and eliminating some major empirical flaws. This figure, which implies a population density of $1 \mathrm{I} .4 / \mathrm{km}^{2}$ and a per capita agrarian output nearing I 4 libras, appears far more reasonable. The full results and a more detailed discussion of this issue can be found in table A4.

\section{Main results}

Two main findings emerge from the present estimates. The first finding is that labor seized the opportunities opened up by the Reconquista and migrated south, thus postponing decreasing returns. Second, that Portuguese per capita agrarian output was considerably higher than that in England, a country struggling with an oversupply of labor. 
The regional distribution of gross and per capita agrarian output is shown in table I. These estimates can be complemented by a rough measure of productivity. In the absence of any detailed data on workforce distribution, a straightforward method is dividing output by rural population, assuming that all population from "urban" (i.e., >5,000 inhabitants) centers worked in services or industry. The estimates compiled in the Atlas de Cidades Medievais (Marques et al. I990) allows us to calculate urban population. Naturally, this only provides a rough indicator as the identification of "urban" and "non-agrarian" does sit well in southern Europe where large "agro-towns" exist, reflecting the concentration of landowners rather than agricultural surplus: Santarém, the archetypal "agro-town", had about the same size as Porto, a service- and manufacture-dominated borough (Viana 2007; Melo 2009).

The per capita data appear more realistic and intelligible if the diocese of Silves is excluded. The parish network of this recently conquered territory was still very loose (only nine parishes) and it concentrated the Muslim minority (whose tithe was paid to the king rather than to the church). With this exception, the distribution of agrarian output is coherent with the "frontier economy" theory. The diocese of Évora, which covered most of the new territory and had the lowest density, has the highest per capita agrarian output, with Lisbon, which also comprised recently occupied territory, not far behind. On the whole, however, differences are slight. The balanced distribution of per capita agrarian output implies that the movement of labor toward new territories led to the equalization of marginal products across the kingdom. Per capita output in densely settled (Braga West, Porto, and Tuy) was not far behind. Freedom of movement meant that surplus workers could relocate to the south in order to obtain land and/or better wages (figure 2).

As with most mainly agrarian economies, the observed inter-regional variation can be attributed to geographical factors. Per capita agrarian output was lower in the landlocked highlands in the interior (Lamego, Viseu, Guarda, and Ciudad Rodrigo) and, to a lesser extent, in the eastern side of the archdiocese of Braga and in Tuy. These overwhelmingly rural dioceses

Table I. Regional distribution of agrarian output in I3II-20 in Portuguese libras

\begin{tabular}{|c|c|c|c|c|}
\hline Diocese & $\begin{array}{l}\text { Agrarian out- } \\
\text { put } \\
\text { (in Iooo libras) }\end{array}$ & $\begin{array}{l}\text { p.c. } \\
\text { Agrarian } \\
\text { output }\end{array}$ & $\begin{array}{l}\text { Agrarian Output/Rural } \\
\text { Population }\end{array}$ & $\begin{array}{l}\text { Pop. per } \\
\mathrm{km}^{2}\end{array}$ \\
\hline Braga East & 916.3 & I3.7 & 13.7 & 9.0 \\
\hline Braga West & $3,501.0$ & I5.7 & I5.7 & 31.7 \\
\hline Ciudad Rodrigo & 72.6 & I0.3 & I0.3 & 4.5 \\
\hline Coimbra & I,469.8 & I 4.9 & I5.8 & II. 5 \\
\hline Évora + Badajoz & I,593.6 & I5.I & I 7.2 & $4 . \mathrm{I}$ \\
\hline Guarda & 873.0 & $\mathrm{I} 2.4$ & $\mathrm{I} 2.4$ & 6.0 \\
\hline Lamego & $69 \mathrm{I} \cdot 3$ & $\mathrm{I} 2.2$ & $\mathrm{I} 2.2$ & I6.6 \\
\hline Lisboa & $2,152.0$ & I3.9 & I6.3 & I5.6 \\
\hline Porto & I, 064.0 & I5.I & 17.0 & 25.6 \\
\hline Silves & I $4 \mathrm{I} .4$ & 5.0 & 5.0 & 5.7 \\
\hline Tuy & $845 \cdot 7$ & $\mathrm{I} 4 . \mathrm{I}$ & I $4 . \mathrm{I}$ & 34.0 \\
\hline Viseu & 843.9 & 12.0 & I2.0 & 18.3 \\
\hline $\begin{array}{l}\text { Average (excluding } \\
\text { Silves) }\end{array}$ & & I3.6 & $\mathrm{I} 4.2$ & I6.I \\
\hline
\end{tabular}

Source: tables $\mathrm{A} 2$ and $\mathrm{A} 4-\mathrm{A} 6$.

Notes: Braga was split in two, separating the eastern highlands (or Trás-os-Montes) from the coastal core of the diocese; likewise, the two parishes of Badajoz were united to the adjacent diocese, Évora. 


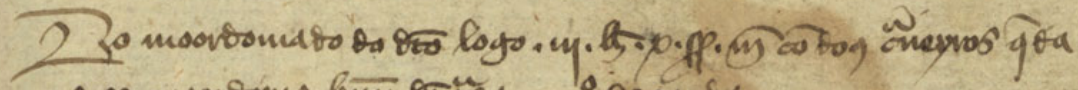

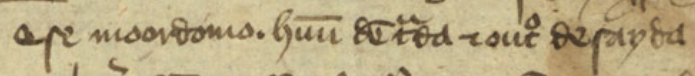

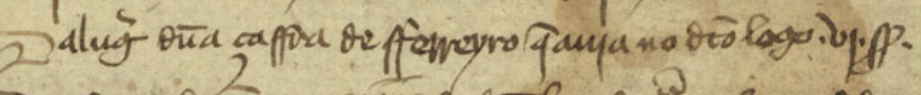

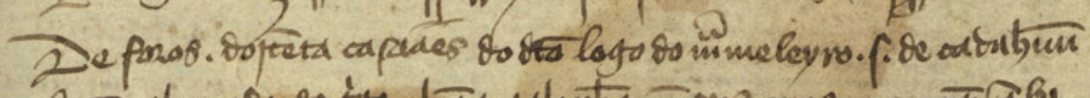

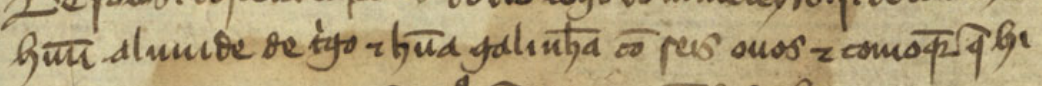

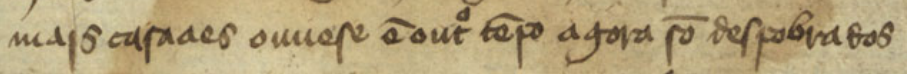

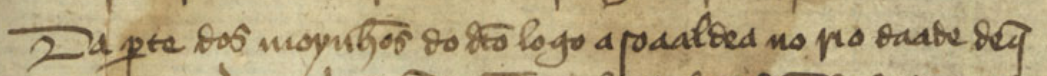

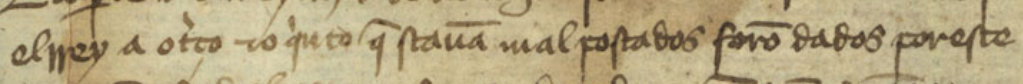

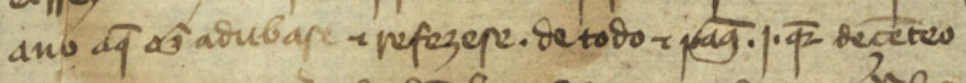

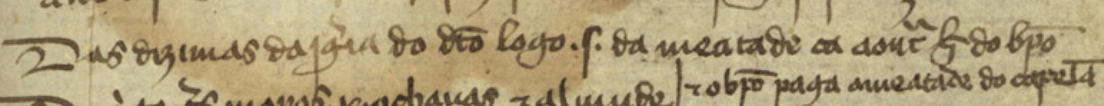

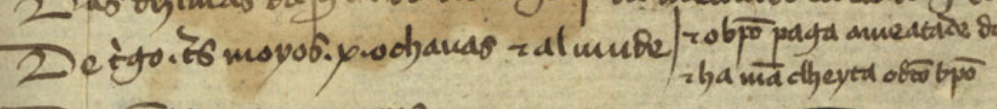

De Eeteo oppopy movar

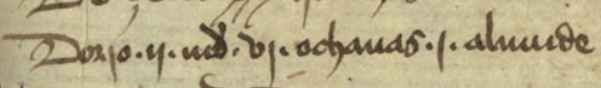

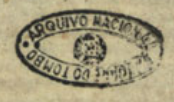

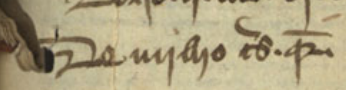

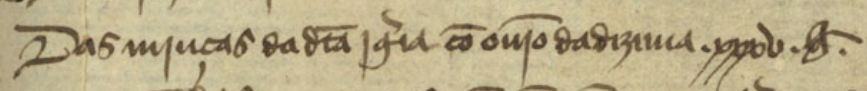

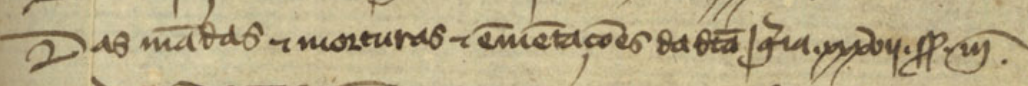

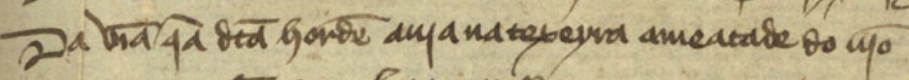

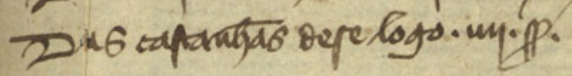

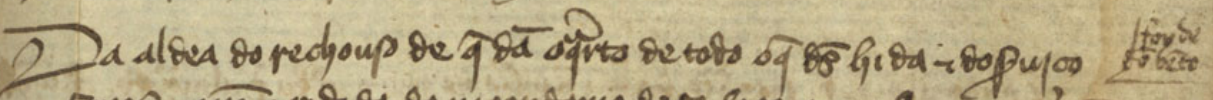

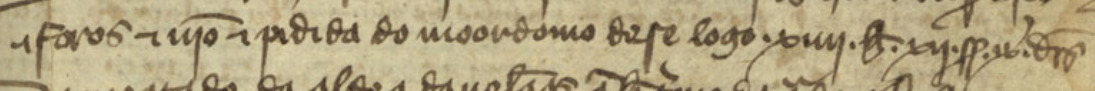

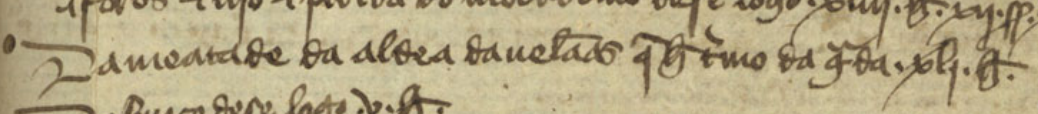

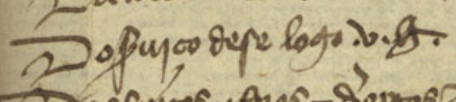

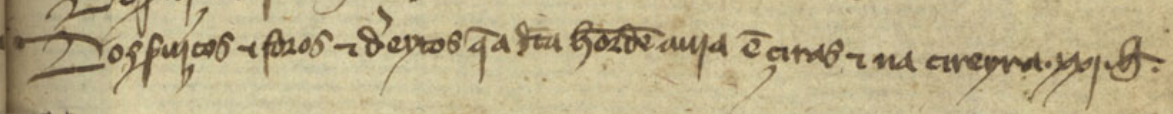
$x+$

Figure 2. Accounts of the Knights Templar. The spiritual revenues of the parish of Marmeleira in 1312, including tithes start at line Io (TT, Ordem de Cristo/Convento de Tomar, mç. I, n. I6, fol. 9).

Copyright: Arquivo Nacional/Torre do Tombo. 


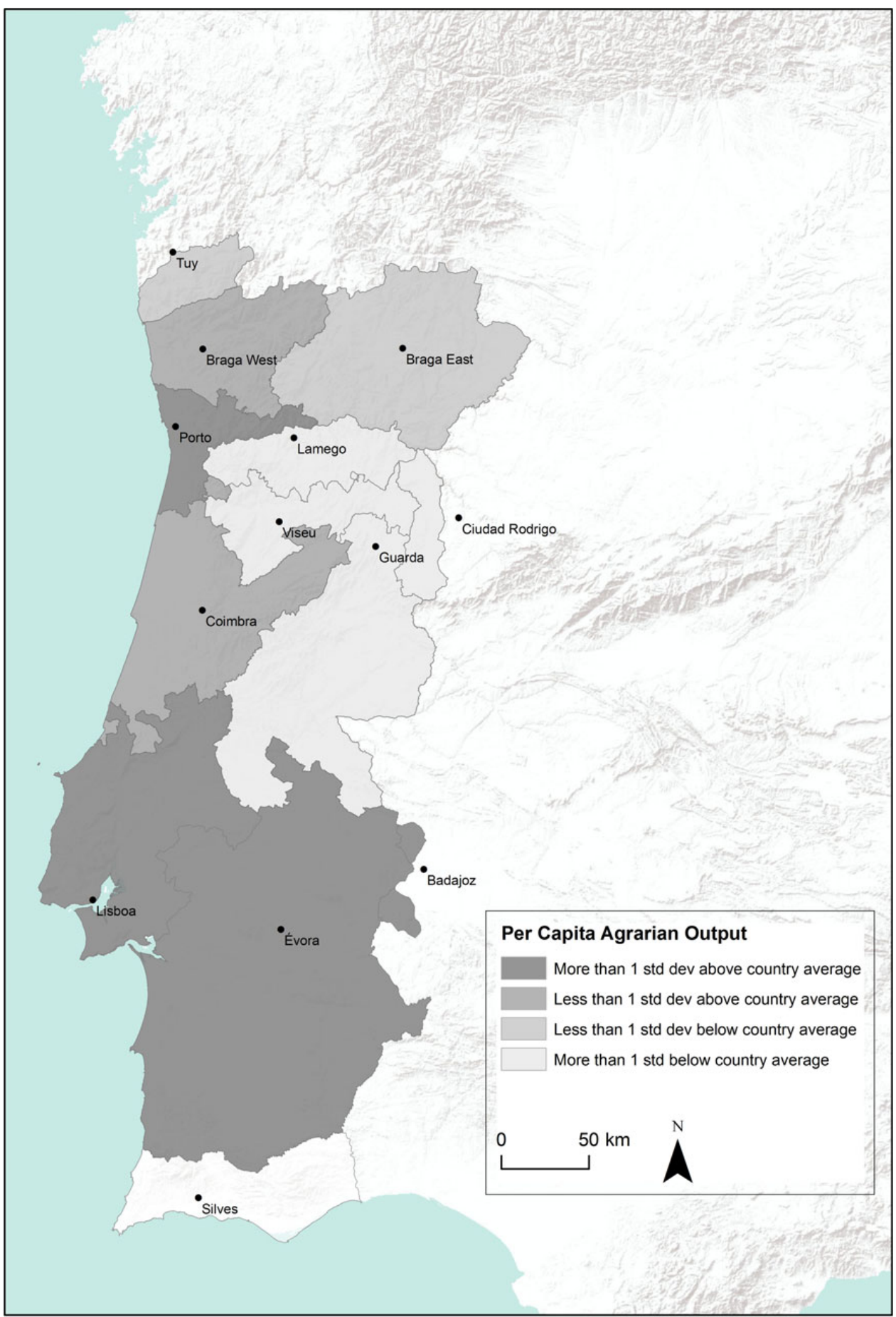

Figure 3. Regional differences in per capita agrarian output. Cartography by Cláudia Viana. 
lacked the adequate conditions for the products which commanded higher prices (wheat or olive oil) (figure 3 ).

The impact of land-abundance in fourteenth-century economies can also be observed with a comparison across Portuguese borders. Unlike output estimates for Italy and Spain, which are expressed in an index form and cannot be readily converted to nominal or real terms, the recent, well-scrutinized output-side estimates for England and Wales (Apostolides et al. 2008, 2012) provide an apt term for comparison (table 2). Mind that consumption patterns were similar, as shown in work by Dyer (1988) and Gonçalves (2004).

Portugal's per capita agrarian output was larger than that of England and Wales c. I300. This result can be related to favorable land/labor ratios. Unlike Portugal, early fourteenth-century England appears pressured by decreasing returns: its demographic density was four times higher (Campbell 2008, table I4). Portugal, on the other hand, was not struggling with excess population and could assign enough land to the pastoral and wine sectors. Wine, in particular, ensured a very good calorie per acre ratio and grew mostly on second-rate soils (Viana I998). In contrast, ale was "land-extravagant" and disputed the space assigned to bread grains (Overton and Campbell 2006, p. I5).

Nevertheless, it should be noted that English and Welsh per capita agrarian output was higher in silver terms, i.e., in terms of exchange rate. This suggests that Portugal's lower agrarian prices also reflect lower demand-side pressure. The land distributions that followed the Reconquista brought on extended land-ownership and access to land via long-term leases for Portuguese farmers. On the whole, this encouraged self-consumption rather than specialization. Pre-Plague England had the inverse problem: a large share of landless workers who had to earn rather than grow their sustenance (Apostolides et al. 2008, p. 32; Campbell 2008, p. 940). England's largely landless waged labor meant that even the basic agrarian goods were already tradable commodities.

These estimates should not be mistaken for a proxy for per capita output, as they do not incorporate the output of the remaining sectors. In England, the agrarian sector only represented half of total output, a share that appears high for Portugal, whose industry did not count any clear exporting sector. The latter country could be likened with the Celtic Fringe, whose superior availability of land did not translate as higher per capita income relative to England (Campbell 2008, pp. 933-4). The terms of trade implicit in this exercise indicate that

Table 2. Agrarian output in Portugal and England, c. I300

\begin{tabular}{lcc}
\hline \hline & Portugal I3I I-20 & England and Wales, I300 s \\
\hline Nominal (in millions) & I4.I6 libras & $£ 2.99$ \\
In tons of pure silver & I69.97 & 956.80 \\
Population (in millions) & I.0 I & 4.25 \\
In grams of pure silver per capita & I68.28 & 218.35 \\
Nominal per capita & I3.99 libras & $£ 0.70$ \\
Real per capita (in I3I I-20 Portuguese libras) & I3.99 & 10.38 \\
\hline \hline
\end{tabular}

Sources: For Portugal, tables A2 and A4-A6; for England, Apostolides et al. (2008, table 18).

Notes: "Real per capita output (in Portuguese 131 I-20 libras)" is the quantity of goods purchased in English current prices $\left(P^{\mathrm{E}}\right)$ by English nominal per capita agrarian output $\left(Q_{\mathrm{pc}}^{\mathrm{N}}\right)$ expressed in Portuguese I3I I-20 prices $\left(P^{\mathrm{P}}\right)$; this can be expressed in notation as $Q_{\mathrm{pc}}^{\mathrm{R}}=\left(Q_{\mathrm{pc}}^{\mathrm{N}} / P^{\mathrm{E}}\right) \times P^{\mathrm{P}}$.

$P^{\mathrm{P}}$ and $P^{\mathrm{E}}$ were based upon a basket composed of grain (half wheat, half rye), mutton, and beer/wine (with I liter of wine equated with 2.66 liters of beer; Allen 2009). The English price for mutton was obtained through extrapolation from the butter, cheese, and milk prices in 1532 (Clark 20I2).

The silver content value of Portuguese libra was I2 g (Marques 1996), while the English pound contained $320 \mathrm{~g}$. 
Portugal would, as it did, export agrarian goods like dried fruits, olive oil, or wine (Marques I978, I 56-7) to Northwest Europe. In exchange, Portugal imported cloths and other manufactures from Northwestern Europe.

It is possible to extend tentatively this comparison to Spain. Álvarez-Nogal and Prados de la Escosura (2013, table 4 and figure 6) attempted a cross-European comparison of per capita GDP in 1300 at constant prices. This was done by applying the reconstructed growth rates of some European countries to a benchmark (I850). If we multiply these results by the share of the agriculture in GDP for England and Spain (Broadberry et al. 2012, table 9; Alvarez-Nogal and Prados de la Escosura 2013, table 6), we have a conjectural measure of per capita agrarian output for 1300 in constant prices. As we estimated Portugal's position relative to England, we can infer Portugal's position relative to Spain through cross-multiplication (table 3 ).

Within the Reconquista countries, Spain's higher agrarian productivity is not surprising given her absolute advantages in terms of extent of the market, higher urbanization rate, manufacturing sectors (cloth and ironworks), and access to the Mediterranean. However, the difference relative to England appears too high. In the absence of sufficient comparative research, we must turn to real wages, which may be taken as a proxy for per capita income and, hence, reflect the living standard of the majority. The available Spanish rural wages and prices used here come from the dynamic region of Zaragoza (Zulaica Palacios 1994). While they might not be representative of the whole of "Spain", these prices and wages underpin the conclusions reached by Álvarez-Nogal and Prados de la Escosura about the favorable pre-I348 period (table 4).

The distance between Portuguese and English wages mirrors the difference between their average per capita agrarian outputs. However, Spanish wages appear lower than those suggested by the data from table 3. At any rate, the real wages of the two "frontier economies" are higher, reflecting their lower pressure on land. If we regard real wages as the marginal return to labor, the worse conditions of the land-scarce English laborers become apparent.

Table 3. Conjectural PPP levels of p.c. agrarian product, c. 1300 (British GDP in $1850=$ IOO)

\begin{tabular}{llll}
\hline \hline PPP method & Spain & England & Portugal \\
$\begin{array}{l}\text { Álvarez-Nogal and Prados de la Escosura dataset } \\
\quad(U S \text { I850 constant prices; British GDP in I850 = I900) }\end{array}$ & 24.2 & I2.5 & I6.9 \\
\begin{tabular}{l} 
Maddison dataset (GK I990 dollars) \\
\hline \hline
\end{tabular}
\end{tabular}

Sources: table 2, and Álvarez-Nogal and Prados de la Escosura (2013, table 4 and figure 6).

Table 4. Unskilled rural day wages, compared, c. I300

\begin{tabular}{llll}
\hline \hline & $\begin{array}{l}\text { Portugal } \\
(\mathrm{I} 3 \mathrm{I} 6-2 \mathrm{I})\end{array}$ & $\begin{array}{l}\text { Aragon } \\
(\mathrm{I} 3 \mathrm{I} 6-2 \mathrm{I})\end{array}$ & $\begin{array}{l}\text { England } \\
\text { (I3I0-19) }\end{array}$ \\
\hline Wage type & Geira & Peón & Farm wage \\
Nominal day wage & 0.125 libras & 5.5 dineros & I.43 pence \\
Grams of silver & $\mathrm{I} .50$ & $\mathrm{I} .74$ & $\mathrm{I} .92$ \\
In real terms (Portuguese I3II-20 libras) & 0.125 & 0.10 & 0.09 \\
Number of days needed to match agrarian output & $\mathrm{II2}$ & {$[\mathrm{I} 70-20 \mathrm{I}]$} & $\mathrm{II} 5$ \\
\hline \hline
\end{tabular}

Sources: table 2; for Aragonese prices and wages: Zulaica Palacios (I994, p. 347, 358, 36I); Serrano Larrayoz (I998). For Spanish p.c. agrarian output: table 3; for Portuguese wages: TT, NA 3I4; ADB, Gaveta das Matérias Inúteis, 38; for English wages: Clark (2007). 
If significant differences between real wages show how decisive the availability of land was in the Malthusian era, Portuguese and Spanish wages appear lower than English when measured in silver content (table 4). This difference mirrors the contrast between Northwestern Europe and Asia, where "grain wages" were higher and "silver wages" lower (Broadberry and Gupta 2006). The higher "silver wages" of Northwest Europe, where urbanization rates were a multiple of Chinese and Indian ones, indicates that labor consumed tradable goods rather than subsistence commodities. Thus, the comparison between Portuguese and Spanish and English wages confirms the former's lower productivity in the traded goods sector. It also suggests that the wide transformations wrought by the Reconquista had differential impacts in Portugal and Spain, due to the latter's higher urbanization rate.

\section{Robustness checks and extensions}

This section discusses whether the main findings are robust to the assumptions adopted and whether the proposed benchmark is coherent with other available information from the demand side, namely consumption baskets.

We claim that frontier economy conditions meant that Portugal's real per capita agrarian product was higher than that of England. Thus, we were careful not to exaggerate Portuguese agrarian output, in fact, while the tithe-to-output coefficient adopted was 9.3 based upon the composition of the product (table A3). Supply-side sources (table 6) suggest a higher share of the pastoral sector (33 percent rather than 17 percent), which would have elevate the tithe-to-output coefficient close to I2. Alternatively, slightly lower values for English agrarian output (Broadberry et al. 2012, table 3) were not considered. Further changes do not matter much: varying the composition of the real deflator would not substantially change the results as all the three main components of the alimentation were less expensive in real terms in Portugal than in England. Applying the lower-bound population estimate for England (4 million) instead of 4.25 million would improve English position relative to Portugal only in 6 percent.

The most disputable issues are the population levels and the coefficients used in the taxatio-to-tithe conversion. We can test the reliability of our assumptions on these issues by postulating that, contrary to our claims, Portugal real per capita agrarian product was equal to England and then observing the implications of this supposition on the taxatio-to-tithe coefficient. As there is uncertainty about population, we tested this contrary assumption with different demographic

Table 5. Testing Portuguese p.c. Agrarian Output, I3II-20

\begin{tabular}{|c|c|c|c|c|}
\hline \multirow{2}{*}{$\begin{array}{l}\text { Variables } \\
\text { All parish assessments at the taxatio } \\
\quad \text { (in libras) }\end{array}$} & \multirow{2}{*}{$\begin{array}{l}\begin{array}{l}\text { Proposed } \\
\text { estimate }\end{array} \\
302,000\end{array}$} & \multicolumn{3}{|c|}{$\begin{array}{l}\text { Alternative estimates assuming that } 1320 \\
\text { Portuguese and } 1300 \text { English p.c. agrarian } \\
\text { outputs were equal }\end{array}$} \\
\hline & & & & \\
\hline $\begin{array}{l}\text { Portuguese } \mathrm{I} 320 \text { p.c. agrarian output } \\
\text { (in libras) }\end{array}$ & I3.99 & I0.38 & & \\
\hline Portuguese population & I.OI million & $\begin{array}{l}\text { Test A } \\
0.7 \text { million }\end{array}$ & $\begin{array}{l}\text { Test B } \\
\text { I million }\end{array}$ & $\begin{array}{l}\text { Test C } \\
\quad \text { I.25 million }\end{array}$ \\
\hline Total tithe (in million libras) & I. 5 & 0.76 & I.I2 & $\mathrm{I} .37$ \\
\hline Net agrarian output (in million libras) & I4. 16 & 7.27 & I0.38 & I 2.98 \\
\hline Implicit taxatio-to-tithe coefficient & 5.0 & 2.5 & $3 \cdot 7$ & $4 \cdot 5$ \\
\hline
\end{tabular}

Sources: tables AI, A2, and A4; and table 2. 
estimates: (A) Mattoso's excessively low original proposal; (B) our preferred estimate (see tables A4-A6); and (C) Portuguese population in 1527-32, which is certainly too high (table 5).

Table 5 indicates that equating English and Welsh to Portuguese per capita agrarian output clashes with the available data. The taxatio-to-tithe coefficient predicted in our estimate is 5.0 and the median tithe/taxatio ratio found in our sample is 4.7 (table AI). The 2.5 coefficient found in Test $\mathrm{A}$ is lower than three and hence impossibly low. The taxatio-to-tithe coefficient of 3.7 obtained under more realistic population figures remains too low considering the data in table Ar: equal or lower coefficients only appear in churches assessed at more than 6oo libras (i.e., 2.9 percent of all parishes). Only by exaggerating population figures (Test C), can the alternative estimate of per capita agrarian output produce a realistic taxatio-to-tithe coefficient.

Other empirical data also indicate that our estimates are solid. If a per capita agrarian output of I3.99 libras is realistic, it has to be consistent with per head demand for agrarian products, given that there were no regular food imports. The consumption patterns across different segments of the population (male/female; urban/rural; and ecclesiastical/lay) can be known through allowances, bequests, and grants to the poor. Importantly, all these allowances are above the subsistence level. This also applies to the grants destined to the pobres vergonçosos (individuals of some standing who had descended into poverty and could not earn their living), as their rationale was to provide these "new poor" with living conditions befitting their previous status (table 6).

Available consumption evidence broadly coincides with the per capita agrarian output of I3.99 libras. This value is very close to the allowances for rural workers in 1364 and impoverished farmers in 1349. These classes got a respectable intake of meat/fish (table A7). With animal protein consumption stable across the rural/urban divide (between 3 I and 34 percent of allowance value), wealthier city-dwellers spend their higher income in wine. This high level of consumption can also be confirmed by pricing Allen's "respectability basket" in contemporary Portuguese prices (Allen 2009, pp. 35-7). While clearly alien to the present setting, this basket provides a recognizable deflator (table 7 ).

This exercise shows that the cost of "respectability" was below per capita agrarian output. In fact, considering the evidence from Portuguese post-Plague consumption baskets, the pre-I348 age must have appeared as a time of plenty. While in England the Plague led to higher high per capita output and real wages, in Portugal, it appears to have coincided with

Table 6. Individual annual consumption in $13 I I-20$ prices

\begin{tabular}{|c|c|c|c|c|c|c|c|c|}
\hline \multirow[t]{3}{*}{ Context } & \multicolumn{4}{|l|}{ Rural } & \multicolumn{4}{|l|}{ Urban } \\
\hline & \multicolumn{2}{|c|}{$\begin{array}{l}\text { Male pobre } \\
\text { vergonçoso (1349) }\end{array}$} & \multicolumn{2}{|c|}{$\begin{array}{l}\text { Male/female } \\
\text { workers (1364) }\end{array}$} & \multicolumn{2}{|c|}{ Poor Clares (I3I8) } & \multicolumn{2}{|c|}{$\begin{array}{l}\text { Male/female pobres } \\
\text { vergonçosos (I328) }\end{array}$} \\
\hline & Libras & Percent & Libras & Percent & Libras & Percent & Libras & Percent \\
\hline Grain & 7.99 & 57 & 8.36 & 65 & 7.55 & 48 & 8.73 & 52 \\
\hline Wine & $\mathrm{I} .23$ & 9 & 0.62 & 5 & 2.88 & I8 & 2.88 & I7 \\
\hline Meat & 4.65 & 33 & 4 & $3 \mathrm{I}$ & 0 & - & 4.63 & 27 \\
\hline Whiting & 0.15 & I & 0 & - & 5.13 & 33 & $0.6 \mathrm{I}$ & 4 \\
\hline Total & \multicolumn{2}{|c|}{ I4.02 libras } & \multicolumn{2}{|c|}{ I2.98 libras } & \multicolumn{2}{|c|}{ I5.56 libras } & \multicolumn{2}{|c|}{ I6.85 libras } \\
\hline
\end{tabular}

Sources: TT, Gavetas, I, 3-I8, and Coelho (I990), Paiva (2003), Amaral (I994), Lopes (2003), Ferreira (2007) and Viana (2007, pp. 104-7).

Notes: See table A7 for quantities in metric units. 
Table 7. Allen's “European Respectability Basket” in I3II-20 Portuguese prices

\begin{tabular}{lccc}
\hline \hline Commodity & Consumption & Price in libras & Cost share (percent) \\
\hline Grain (liters needed for 234 kg bread) & 360.6 & 6.1 I & 58.6 \\
Wine (liter) & 68.3 & 0.60 & 5.7 \\
Meat (kg) & 26.0 & 1.20 & II.6 \\
Olive oil (liter) & 7.8 & 0.64 & 6.1 \\
Wood (kg) & 70.8 & 0.33 & 3.2 \\
Vegetables (liter) & 52.0 & 0.78 & 7.5 \\
Eggs & 52.0 & 0.05 & 0.5 \\
Cheese & 5.2 & 0.24 & 2.3 \\
Soap & 2.6 & 0.12 & 1.2 \\
Linen & 5.0 & 0.29 & 2.8 \\
Candle & 2.6 & 0.03 & 0.3 \\
Lamp oil & 2.6 & 0.03 & 0.2 \\
Total & & 10.43 & 100 \\
\hline \hline
\end{tabular}

Sources: Allen (200I, 2009) and Ferreira (2007).

Notes: (I) non-agrarian components of baskets were not considered; (2) as some prices come from later periods, there might be an upward bias in the total cost; (3) "grain" price is the mean between wheat and rye prices (this was a common combination in bread); and (4) conversion of bread into grain used the extraction rates, losses and specific densities indicated (Gonçalves 1999, pp. 236-7).

a drop in the standards of living. In the early fifteenth century, institutions across the country had to reduce their statutory food allowances defined before the Plague (Mata 2000, p. 5I, 264; Rocha 20I I, p. 76, 232; Fontes I998, p. 229; TT, Gavetas, I, 4-25). This cannot be attributed to the excess population, as there are complains about the shortage of people in the $1420 \mathrm{~s}$ and I430s (Marques and Dias 1994). Considering the case of Spain, where population decline led to the decay in living standards, this evidence is not surprising (Álvarez-Nogal and Prados de la Escosura 2013, p. 24). Instead of releasing the Peninsula from population pressure, the Black Death and subsequent mortality crises led to the disintegration of product and factor (namely labor) markets.

\section{Conclusions}

Around I300, having plenty of land meant being a land of plenty. Portuguese real per capita agrarian output and real wages were higher than those of England and Wales and were clearly above subsistence level. This difference cannot be attributed to superior technology or institutions but to a far more comfortable labor/land ratio. When combined with freedom of movement for labor, plenty of land meant increasing returns to labor and relatively high wages. This advantage stems from the Reconquista, which released population pressure by killing, banishing, or dispossessing the peninsular Moors.

Whilst low population density and wide availability of land kept Malthusian checks at bay, weak market integration, thin labor markets, low levels of specialization, and perhaps insufficient monetary supply probably meant that Portugal was not meeting the conditions associated with the Little Divergence. These problems were aggravated by the Black Death, which seems to have contributed to deteriorate living standards in the Reconquista countries, while improving the conditions of northwestern Europe (Pamuk 2007; Voigtländer and Voth 2013). 


\section{Acknowledgements}

Earlier versions of this article were presented at seminars held in Lisbon (ICS and FSCH-Nova) and Ponta Delgada, and also at the 3Ist APHES Conference in Coimbra. The author would like to thank first Mário Farelo, Nuno Palma, and Jaime Reis, the referees and the editors, in particular Hans-Joachim Voth. The author would also like to thank Nuno Amado, Fátima Brandão, Steven Broadberry, José Luís Cardoso, Rui Pedro Esteves, Dulce Freire, Pedro Lains, Nuno Moutinho, Pedro Vaz Santos, Filipe Castro Soeiro, Pedro Teixeira, and Cláudia Viana.

Conflict of interest statement. None declared.

\section{References}

Allen, R.C. (200I). The Great Divergence in European wages and prices from the Middle Ages to the First World War. Explorations in Economic History 38, pp. 4I I-447.

Allen, R.C. (2009). The British Industrial Revolution in Global Perspective. Cambridge: Cambridge University Press.

Almeida, F.D. (I9I0-28). História da Igreja em Portugal. Lisboa: Civilização.

Álvarez-Nogal, C. and Prados de la Escosura, L. (2013). The rise and fall of Spain (1270-1850). The Economic History Review 66, pp. I-37.

Amaral, L.C. (1994). São Salvador de Grijó na Segunda Metade do Século XIV. Estudo de Gestão Agrária. Porto: Cosmos.

Apostolides, A., Broadberry, S., Campbell, B., Overton, M. and van Leeuwen, B. (2008). English agricultural output and labour productivity, I250-1850: some preliminary estimates. Unpublished Working Paper, University of Warwick.

Arquivo Distrital de Braga, Braga (ADB). Gaveta das Matérias Inúteis. No. 38.

BarRos, M.F.L.D. (2007). Tempos e espaços de mouros: A minoria muçulmana no reino português (séculos XII a $X V)$. Lisboa: FCT/Fundação Calouste Gulbenkian.

BARbosa, P.G. (1992). Povoamento e Estrutura Agrícola na Extremadura Central. Século XII a I325. Lisbon: INIC.

BoIsSEllier, S. (2012). La Construction Administrative d'un royaume: registres de bénéfices ecclésiastiques portugais (XIII-XIVe siécles) Lisbon: CEHR.

Broadberry, S., Campbell, B.M.S., Klein, A., Overton, M. and Van Leeuwen, B. (2012). British Economic Growth: 1270-I870: an output-based approach. School of Economics Discussion Papers, University of Kent.

BroAdBerRy, S. and Gupta, B. (2006). The Early Modern Great Divergence: Wages, Prices and Economic Development in Europe and Asia, I500-I800. Economic History Review 59, pp. 2-3I.

CAMpBell, B.M.S. (2008). Benchmarking medieval economic development: England, Wales, Scotland and Ireland, c. I290. Economic History Review 6I, pp. 896-945.

Clark, G. (2007). The long march of history: farm wages, population and economic growth, England I209-I869. Economic History Review 6o, pp. 97-136.

CLARK, G. (2010). The macroeconomic aggregates for England, I209-2008. Research in Economic History 27, pp. 5I-I40.

Clark, G. (2012). England_I209-I9I4. Database at gpih.ucdavis.edu/files/England_I209I9I4_(Clark).xls (accessed March 20I4).

Coelho, M.H.D.C. (I990). Apontamentos sobre a comida e a bebida do campesinato coimbrão em tempos medievos. In M.H.D.C. Coelho, (ed), Homens, espaços e poderes: séculos XI-XVI, Vol. I. Lisboa: Livros Horizonte, pp. 9-22.

Costa, A.D.J.D. ([1959] 1997-2000). O Bispo D. Pedro e a organização da Diocese de Braga. Braga: Irmandade de $\mathrm{S}$. Bento da Porta Aberta.

Crafts, N. and Mills, T. (2009). From Malthus to Solow: how did the Malthusian economy really evolve. fournal of Macroeconomics 3I, pp. 68-93.

Dias, J.J.A. (1996). Gentes e Espaços. Em torno da população portuguesa na primeira metade do século XVI. Lisbon: Fundação Calouste Gulbenkian/JNICT. 
DinIs, A. (1960). Monumenta Henricina. Coimbra: Atlântida.

Dyer, C. (1988). Changes in diet in the Late Middle Ages: the case of harvest workers. Agricultural History Review 36, pp. 21-37.

Esteves, R.P. (2003). The Portuguese Concelhos and Forais. A case in institutional history from the eleventh to the mid thirteenth centuries.

Fernandes, H. (2000). Entre Mouros e Cristãos. A Sociedade de Fronteira no Sudoeste Peninsular interior (sécs. XII-XIII). Faculdade de Letras, PhD. Lisbon.

FerreIRA, M.D.C.F. (1988). Os Besteiros do Conto de Guimarães na Centúria de Trezentos. Revista de Ciências Históricas 3, pp. 183-216.

Ferreira, S.C. (2007). Preços e Salários em Portugal na Baixa Idade Média. Faculdade de Letras, Mestrado. Porto: Universidade do Porto.

Fontes, J.L.I. (1998). Frei João Álvares e a tentativa de reforma do mosteiro de S. Salvador de Paço de Sousa no século XV. Lusitania Sacra 10 (series 2), pp. 217-302.

Gomes, S.A. (1998). As ordens mendicantes na Coimbra medieval: notas e documentos. Lusitania Sacra Io (series 2), pp. I49-215.

Gonçalves, I. (I989). O Património do Mosteiro de Alcobaça nos séculos XIVe XV. Lisboa: FCSH-UNL.

Gonçalves, I. (I999). Sobre o Pão Medieval Minhoto. O Testemunho das Inquirições de I258. Arqueologia Medieval (6), pp. 225-243.

GonÇALVES, I. (2004). Entre a abundância e a miséria: as prácticas alimentares da Idade Média portuguesa. In I. Gonçalves (ed), Estudos Medievais. Lisboa: Livros Horizonte.

Gonçalves, I. (2010). Comendas da Beira Interior Centro. Lisboa: Centro de Estudos Históricos.

Henriques, A.C. (2013). O "Fruto" e o Produto. Do dízimo eclesiástico às contas nacionais (Portugal, século XIV). In M. Viana and J.A. Solorzano Telechea (eds), Economia e Instituições na Idade Média. Novas Abordagens. Ponta Delgada: Centro de Estudos Gaspar Frutuoso, pp. 66-94.

Johnson, H.B. (1970). Para a História Social de Torres Vedras, um documento eclesiástico de I309. Boletim Cultural da funta Distrital de Lisboa 73-74, pp. 59-74.

Kelly, M. and Ó. GrádA, C. (2013). Living Standards and Mortality Since the Middle Ages. Dublin: University College.

Lopes, F.F. (I966). Para a História de Torres Vedras. Lusitania Sacra VII, pp. I35-52.

Lopes, L.S. (2003). Sistemas Legais de Medidas de Peso e Capacidade, do Condado Portucalense ao Século XVI. Portvgalia Nova Série XXIV, pp. II3-64.

Malanima, P. (2009). Pre-modern European Economy. One Thousand Years (Ioth-Igth Centuries). Leiden: Brill.

Malanima, P. (2010). The long decline of a leading economy: GDP in central and northern Italy, I3001913. European Review of Economic History, pp. 169-219.

Marques, A.H.D.O. (197I). Daily Life in Portugal in the Later Middle Ages. Madison: University of Wisconsin Press.

Marques, A.H.D.O. (1978). Introdução à História da Agricultura em Portugal. A Questão Cerealífera em Portugal na Idade Média. Lisbon: Cosmos.

Marques, A.H.D.O. (1980). A População Portuguesa nos Fins do Século XIII. In A.H.D.O. Marques (ed), Ensaios de História Medieval Portuguesa. Lisbon: Vega, pp. 5I-92.

MARques, A.H.D.O. (198I). Introdução à Histórida da Cidade Medieval Portuguesa. Bracara Augusta 35, pp. 3-23.

MARQUES, A.H.D.O. (1987). Portugal na Crise dos Séculos XIV e XV. Lisbon: Presença.

Marques, J. (1988). A Arquidiocese de Braga no Século XV. Lisbon: INCM.

Marques, M.G. (1996). História da Moeda Medieval Portuguesa. Sintra: Instituto de Sintra.

MArques, A.H.D.O. and Dias, J.J.A. (1994). A População Portuguesa nos Séculos XVe XVI. Biblos LXX, pp. I7I-96.

Marques, A.H.D.O., Gonçalves, I. and Andrade, A.A. (I990). Atlas de cidades medievais portuguesas: (séculos XII a XV). Lisboa: Centro de Estudos Históricos da Universidade Nova.

Mata, L.A.S.N. (2000). Ser, ter e poder: o Hospital do Espirito Santo de Santarém nos finais da Idade Média. Leiria: Magno Edições. 
Mattoso, J. (200I). A Identificação de um País. Ensaio sobre as origens de Portugal (I096-1325). Lisbon: Círculo de Leitores.

Melo, A.D.S. (2009). Trabalho e Producão em Portugal na Idade Média:O Porto, c. 1320-c. I4I5, PhD. Braga: Universidade do Minho.

Nicolini, E. (2007). Was Malthus right? A VAR analysis of economic and demographic interactions in pre-industrial England. European Review of Economic History II, pp. 99-I2I.

Oliveira, L.F. (2012). As Definições da Ordem de Avis de i327. In I.C.F. Fernandes (ed), As Ordens Militares. Freires, Guerreiros, Cavaleiros. Actas do VI Encontro sobre Ordens Militares, Vol. I. Palmela: GEsOS/Município de Palmela, pp. 37I-388.

Overton, M. and CAmpbell, B.M.S. (2006). Production and productivity in English Agriculture Io86I87I. In B.M.S. Campbell (ed), I4th International Economic History Congress, Helsinki, Finland.

Parva, J.P. (2003). Antes das Misericórdias. Lisboa: União das Misericórdias Portuguesas.

Pamuk, S. (2007). The Black Death and the origins of the 'Great Divergence' across Europe, I300-1600. European Review of Economic History II, pp. 289-317.

Rau, V. (1982). Sesmarias Medievais Portuguesas. Lisboa: Presença.

RePAs, L. (2003). Quando a nobreza traja de branco. A comunidade cisterciense durante o Abadessado de D. Luca Rodrigues (I286-I299). Leiria: Magno.

Rocha, A.R.S.D. (20I I). A Institucionalização dos Leprosos. O Hospital de S. Lázaro de Coimbra nos séculos XIII a XV. Faculdade de Letras, Mestrado. Coimbra: Universidade de Coimbra.

RODRIGUes, T. (2008). História da população portuguesa : das longas permanências à conquista da modernidade. Porto: Afrontamento.

SÁ NogueirA, B. (2008). Tabelionado e Instrumento Público em Portugal. Génese e Implantação (I212-I279). Lisbon: INCM.

SARAIVA, M.T.M.P. (1997). Figueira, comenda da ordem de Avis (publicação de fontes). Lisboa: Colibri.

SERRANo LARrayoz, F. (I998). La alimentación de la realeza navarra en el siglo XV. In J.I. IgLesia Duarte (ed), La vida cotidiana en la Edad Media. Logrono: Gobierno de la Rioja, pp. 305-336.

Silva, M.J.O.E. (2010). A escrita na Catedral: a Chancelaria Episcopal do Porto na Idade Média: (Estudo Diplomático e Paleográfico). PhD. Porto: Universidade do Porto.

Torre do Tombo, Lisbon (TT). Núcleo Antigo, no. 314.

Torre do Tombo, Lisbon (TT). Ordem de Cristo/Convento de Tomar. Maço I, no. I6.

Torre do Tombo, Lisbon (TT). Ordem de Santiago/Convento de Palmela, DR. Maço I, no. 25.

Torre Do Tombo, Lisbon (TT). Gavetas. Gaveta I, Maço 3, no. I8.

Torre Do Tombo, Lisbon (TT). Gavetas. Gaveta I, Maço 4, no. 25.

Viader, R. (20I0). La dîme dans l'Europe des Feodalités. In R. Viader (ed), La Dîme. Actes des XXXes Fournées Internationales d'Histoire de l'Abbaye de Flaran. Flaran: Presses Universitaires du Mirail, pp. 7-36.

Viana, M. (1998). Os Vinhedos Medievais de Santarém. Cascais: Patrimonia Historica.

Viana, M. (2007). Espaço e Povoamento numa Vila Portuguesa (Santarém II47-1350). Lisbon: Caleidoscópio.

VILAR, H.V. (I996). Uma fronteira entre poderes: as dioceses de Évora e da Guarda no nordeste alentejano.

Revista de Guimarães 106, pp. I52-274.

VIlar, H.V. (I999). As Dimensões de um Poder. A diocese de Évora na Idade Média. Lisboa: Estampa.

VILAR, H.V. (2007). Patronage, parochial rights and military Portugal. Some analytical perspectives. In R. Czaja and J. Sarnowsky (eds), Die Ritterorden als Träger der Herrschaft: Territorien, Grundbesitz und Kirche. Turun: Nicolai Copernici Universitas, pp. 203-223.

Viterbo, J.D.S.R.D. (1966). Elucidário das palavras, termos e frases que em Portugal antigamente se usaram. Porto: Civilização.

VoigtländeR, N. and Voth, H.-J. (2013). The three Horsemen of Riches: plague, war, and urbanization in early modern Europe. Review of Economic Studies 8o, pp. 774-8I I.

ZANDEN, J.L.V. and LEEUwEN, B.V. (2OI I). The Character of growth before 'modern economics growth'? The GDP of Holland between 1347 and I807. Working Papers. Centre for Global Economic History, Utrecht University.

Zulaica Palacios, F. (1994). Fluctuaciones económicas en un periodo de crisis. Precios y salarios en Aragón en la Baja Edad Media (I300-I430). Zaragoza: Universidad de Zaragoza. 


\section{Appendix A}

Table Ar. Parish tithe accounts (at I3II-20 prices in Portuguese libras) and the taxatio

\begin{tabular}{|c|c|c|c|c|c|}
\hline \multicolumn{2}{|c|}{ Parish (Diocese) } & \multirow{2}{*}{$\begin{array}{l}\text { Taxatio } \\
\text { assessment }\end{array}$} & \multicolumn{2}{|c|}{ Parish revenues } & \multirow{2}{*}{$\begin{array}{l}\text { Tithe/taxatio } \\
\text { ratio }\end{array}$} \\
\hline & & & Tithe $^{\mathrm{a}}$ & Other & \\
\hline I3I 2 & Santa Maria do Templo (Guarda) & O & $7 \cdot 5^{\mathrm{c}}$ & 2.4 & - \\
\hline I3I 2 & Rapoula (Guarda) & I5 & $107^{\mathrm{c}}$ & 6.2 & $7 . \mathrm{I}$ \\
\hline 1312 & Marmeleiro (Guarda) & IOO & $777^{\mathrm{c}}$ & I.9 & 7.8 \\
\hline 1312 & Touro (Guarda) & $100^{b}$ & $47 I^{c}$ & 30.5 & $4 \cdot 7$ \\
\hline $1300-9$ & São Pedro de T. Vedras (Lisboa) & 280 & $\mathrm{I}, 903^{\mathrm{c}}$ & n.a. & 6.5 \\
\hline $1300-9$ & São Miguel de T. Vedras (Lisboa) & 500 & $2,395^{\mathrm{c}}$ & n.a. & 4.8 \\
\hline $1300-9$ & Santiago de T. Vedras (Lisboa) & 605 & $\mathrm{I}, 82 \mathrm{I}^{\mathrm{c}}$ & n.a. & 3.0 \\
\hline $1300-9$ & Santa Maria de T. Vedras (Lisboa) & 700 & $2,737^{\mathrm{c}}$ & n.a. & $3 \cdot 9$ \\
\hline I327 & Avis (Évora) & $\mathrm{I}, 73 \mathrm{I}$ & $6,4 \mathrm{I9}$ & 300 & $3 \cdot 7$ \\
\hline I3I6 & Tomar (Lisboa) & 5,000 & 12,378 & n.a. & 2.5 \\
\hline
\end{tabular}

Sources: I300-9: Lopes (I966) and Johnson (I970); I3I2-I6: TT, Ordem de Cristo/Convento de Tomar, I-I6 and I327: Oliveira (20I2).

${ }^{a}$ Gross yield of the tithe, comprising all shares; as, except for $1300-9$, all accounts were net of the third given to the bishop, thus tithes in Avis, Templo and Touro were multiplied by I.5 allowing for the bishop's third (Vilar I996, p. 254, Gonçalves 20I0, p. I73), Marmeleira by 2.0 and Rapoula by I.o as the bishop was entitled to, respectively, one-half and nothing (TT, Ordem de Cristo/Convento de Tomar, I-I6; Gonçalves 20I0, p. I73);

${ }^{b} 2$ libras were deduced from Touro in order to allow for a chapel assessed together with the parish in 1320 (Boissellier, 20I2, p. I95).

${ }^{c}$ Prices of the tithes in grain are given by the troika: I alqueire (i.e., 9.825 liters) of wheat at 0.2 libras and of second-rate grain at 0.I I6 libras; wine was valued according to the I3I2 accounts: I almude (i.e., 8.33 liters) at 0.05I25 libras; with "grain" in $1300-9$ interpreted as two-third wheat.

Table A2. The taxatio (all values in libras)

\begin{tabular}{|c|c|c|c|}
\hline Dioceses ( $n$ parishes) & $\begin{array}{l}\text { Median value of } \\
\text { parish assessment }\end{array}$ & $\begin{array}{l}\text { Total value of } \\
\text { parish assessments }\end{array}$ & $\begin{array}{l}\text { Estimated } \\
\text { total tithe }\end{array}$ \\
\hline Braga (946) & 55 & 87,449 & $4,417,025$ \\
\hline Ciudad Rodrigo (55) & I5 & 992 & 72,608 \\
\hline Coimbra (227) & 100 & 30,714 & I,469,792 \\
\hline Évora + Badajoz $\left(\mathrm{IO}_{3}+2\right)$ & 300 & 40,409 & $\mathrm{I}, 593,62 \mathrm{I}$ \\
\hline Guarda (205) & 40 & 17,325 & 872,974 \\
\hline Lamego (II9) & 72.5 & 13,929 & $69 I, 313$ \\
\hline Lisboa (136) & 290 & 55,830 & $2,152,004$ \\
\hline Porto (277) & 50 & 19,453 & $\mathrm{I}, 064,023$ \\
\hline Silves (8) & 247.5 & 3,623 & $\mathrm{I} 4 \mathrm{I}, 388$ \\
\hline Tuy (I83) & 60 & 16,440 & 845,732 \\
\hline Viseu (I62) & 85 & I6,IO4 & 843,870 \\
\hline Total (24I3) & - & 302,267 & $\mathrm{I} 4, \mathrm{I} 64,348$ \\
\hline
\end{tabular}

Source: Boissellier (2012, pp. III-203).

Notes: (a) Assessments include I03 parish churches attached to monasteries to which we assigned a value equal to the median of the parish churches within their archdeaconry. (b) For practical reasons, the value of I was given to I 5 parishes assessed at "o". 
Table A3. Agrarian output composition in three large parishes (in libras)

\begin{tabular}{|c|c|c|c|c|c|c|c|c|c|}
\hline \multirow[t]{3}{*}{ Commodities tithed } & \multicolumn{3}{|c|}{ Tomar 1316 } & \multicolumn{3}{|c|}{ Tomar 1326} & \multicolumn{3}{|c|}{ Avis 1327} \\
\hline & \multirow[t]{2}{*}{ Tithe } & \multicolumn{2}{|c|}{ Tithe adjusted } & \multirow[t]{2}{*}{ Tithe } & \multicolumn{2}{|c|}{ Tithe adjusted } & \multirow[t]{2}{*}{ Tithe } & \multicolumn{2}{|c|}{ Tithe adjusted } \\
\hline & & Libras & Percent & & Libras & Percent & & Libras & Percent \\
\hline Wheat & 4,048 & 3,036 & 40 & 5,360 & 4,020 & 55 & 540 & 405 & I7 \\
\hline Other grain & I,555 & I,I66 & I6 & & & & 420 & 315 & I3 \\
\hline Wine & 775 & 752 & IO & $\mathrm{I}, 000$ & 970 & I3 & $\mathrm{I}, 500$ & $\mathrm{I}, 350$ & 55 \\
\hline Olive oil & $\mathrm{I}, 300$ & $\mathrm{I}, \mathrm{I} 7 \mathrm{O}$ & I5 & $\mathrm{I}, \mathrm{OOO}$ & 900 & $\mathrm{I} 2$ & & & \\
\hline Livestock & 350 & $I, 295$ & 17 & 350 & $\mathrm{I}, 295$ & I8 & 160 & 364 & I5 \\
\hline Other & I 22 & $\mathrm{I} 22$ & 2 & I 20 & $\mathrm{I} 20$ & 2 & 20 & 20 & I \\
\hline Totals & 8,150 & $7,54 \mathrm{I}$ & 100 & 7,830 & 7,458 & 100 & 3,263 & 3,247 & IOI \\
\hline $\begin{array}{l}\text { Tithe adjusted } \\
\text { as percent of Tithe }\end{array}$ & & 0.93 & & & 0.93 & & & 0.93 & \\
\hline
\end{tabular}

Sources: I3I6: TT, Ordem de Cristo/Convento de Tomar, I-I6; I326: Dinis (I960: I, pp. I50-I60); I327: Oliveira (2012).

Notes: The 3.7 coefficient for adjusting livestock tithe is taken from Henriques (2013, p. 87).

Table A4. Portuguese population, c. 1300

\begin{tabular}{|c|c|c|c|}
\hline Diocese & Population (in rooo hab.) & Density (hab./ $/ \mathrm{km}^{2}$ ) & $\begin{array}{l}\text { Change in population distribution } \\
\text { (relative to } 1527-32)(\%)\end{array}$ \\
\hline Braga (East) ${ }^{\mathrm{a}}$ & 67.1 & 8.99 & +0.1 \\
\hline Guarda & 70.6 & 6.03 & +2.3 \\
\hline Viseu & 70.6 & I8.30 & -0.6 \\
\hline Porto & 70.6 & $25 \cdot 58$ & +0.9 \\
\hline Braga $\left(\right.$ West) ${ }^{\mathrm{a}}$ & 120.0 & $44.4 \mathrm{I}$ & -6.7 \\
\hline Braga $\left(\right.$ Center) ${ }^{a}$ & I02.4 & 23.75 & n.a. \\
\hline Tuy & 60.0 & 34.01 & +2.6 \\
\hline Coimbra & 98.8 & II .52 & +0.5 \\
\hline Évora & 105.9 & 4.09 & +3.7 \\
\hline Lisboa & I $55 \cdot 3$ & 15.62 & +0.5 \\
\hline Lamego & 56.5 & I6.57 & +0.1 \\
\hline C. Rodrigo & 7.1 & $4 \cdot 47$ & $+\mathrm{I} . \mathrm{I}$ \\
\hline Silves & 28.2 & 5.69 & +0.7 \\
\hline
\end{tabular}


Table A4. Continued

\begin{tabular}{llll}
\hline \hline Diocese & Population (in IOo0 hab.) & Density $\left(\mathrm{hab} . \mathrm{km}^{2}\right)$ & $\begin{array}{l}\text { Change in population distribution } \\
\text { (relative to I527-32) }(\%)\end{array}$ \\
\hline Total & I,013.0 & II.4 & \\
\hline \hline
\end{tabular}

Portuguese population prior to the $1527-32$ census, which indicates a population of $\mathrm{I} .25$ million (Dias, I996), is a contentious topic. Marques and Dias stated that in the absence of any technological breakthrough the pre-Plague Portuguese population peak would be only recovered by I600. As such, he ventured that population peaked at I.5 million in 1348 (Marques and Dias 1994, p. 176). In contrast, the latest educated guess on Portuguese population (Rodrigues 2008, p. 5I9) claims that the population in 1340 was around 900,000 souls and that it was only 800,000 by 1320. These round figures are loosely extrapolated from the lower-bound estimates by Mattoso (200I, pp. I4-I8).

The demographic trajectory advanced by Marques and Dias appears more consistent with the European evolution up to the Black Death (Pamuk 2007, p. 294; Malanima 2009), while revisionist by Mattoso estimates appear too low. Nonetheless, the notion that Portuguese population in I527-32 was still below Pre-Plague levels is inconsistent with other data. Research (Marques I988; Costa [1959] I997-2000, p. 242) shows that in the rural parishes of the most densely populated part of the country (Entre Douro e Minho), the number of households changed little between I 258 and I527. This stability seems to fit the structuraliste theory of Oliveira Marques. Yet, the comparison of the population distribution found by Mattoso with that of the 1527-32 census shows that the weight of this region in the overall population diminished from 25.7 to I 9.6 percent. If this region kept its absolute population level but lost weight relative to other regions, it follows that the remaining regions were necessarily more populated in $1527-32$ than that in 1300 . Thus, in 1527-32 Portuguese population had to be greater than it in I3II-20. This is coherent with other evidence, namely the large-scale imports of wheat in Lisbon and other coastal cities in the fifteenth and sixteenth centuries. Thus, by I300 population stood somewhere between Mattoso's lowly 0.7 million and the excessive I.25 million of I527-32. This interval becomes shorter if we correct the calculations made by Mattoso. In fact, Mattoso made no attempt to make up for the flaws of the source neither the errors of its edition (Marques I980). First, he did not take into account active notaries absent from the 1290 document (episcopal notaries from Porto and Braga, those from major towns like Beja, Setúbal or Tomar and those Algarve and Castelo Rodrigo). Second, the editor assigned five notaries to the wrong regions. Third, Mattoso assigned I20,000 souls to the whole of the Entre Douro e Lima (totaling 6,022 $\mathrm{km}^{2}$ ) although Costa had estimated at $c$. I I 0,000 the population of the $2,580 \mathrm{~km}^{2}$ area between the rivers Lima and Ave-Vizela (Costa [I959] I997-2000, p. 248), the country's most populous region. This was a major flaw as it contributed to understating the density of the region for which A. J. da Costa had reconstructed the number of households and, indirectly, of the entire kingdom. These flaws are corrected here. Furthermore, in order to allow for the different demographic implications of rural and urban notaries, notaries working in rural districts were counted as $\mathrm{I} .25$, whereas notaries working in towns were counted as 0.8 . Notaries assigned to municipalities combining a town with a rural district were kept as I. This is a crude way of compensating for the concentration of notaries public in cities and towns. The corrections resulted in adding 300,000 souls that had been lost by Mattoso.

Sources: Unless stated, data are obtained from Marques et al. (I990), Marques (I980), and Mattoso (200I). Notes: (a) The diocese of Braga was divided in order to separate the region studied by Costa (Braga West), the markedly different region of Trás-os-Montes (Braga East) and the core of the diocese (Braga Center). 
Table A5. Urban population, c. ${ }^{3} 300^{a}$ (in I000 hab.)

\begin{tabular}{llll}
\hline \hline Cities & Existing estimates & Adopted estimate & In the I527-32 census \\
\hline Lisbon & I5.8-35.0 & I6 & 59 \\
Évora & 8,2 & 8 & I3 \\
Porto & $4.4-7.6$ & 8 & I 4 \\
Santarém & 7.2 & 7 & 9 \\
Coimbra & 6.4 & 6 & I 8 \\
Elvas & 4.8 & 5 & II \\
Leiria & 4.5 & 4 & 3 \\
Guimarães & $2.3-4.5$ & 2 & 6 \\
Braga & 2.5 & 2 & 9 \\
Guarda & I.6 & 2 & 2 \\
Silves & $\mathrm{I} .6$ & 2 & 7 \\
\hline \hline
\end{tabular}

Source: see table A6.

${ }^{a}$ Unless stated, data are obtained from Marques et al. (I990).

Table A6. Urban indicators

\begin{tabular}{|c|c|c|c|c|}
\hline Cities & $\begin{array}{l}\text { Built area (in hectares) } \\
\text { (walled }+ \text { non-walled) }^{\text {a }}\end{array}$ & $\begin{array}{l}\text { Notaries } \\
\text { In } 1290^{b}\end{array}$ & $\begin{array}{l}\text { Parishes } \\
\text { In } 1320\end{array}$ & $\begin{array}{l}\text { Crossbowmen } \\
\text { levied, } c .1300^{\mathrm{b}}\end{array}$ \\
\hline Lisbon & $98(60+38)$ & $2 \mathrm{I}$ & 23 & n.a. \\
\hline Évora & $>_{5 \mathrm{I}}(5 \mathrm{I}+?)$ & 5 & 5 & n.a. \\
\hline Porto & $48(4+44)$ & $6^{\mathrm{d}}$ & 3 & n.a. \\
\hline Santarém & $45(33+12)$ & 15 & 15 & 60 \\
\hline Coimbra & $40^{c}(?+?)$ & 5 & 6 & $3 \mathrm{I}$ \\
\hline Elvas & $>30(30+?)$ & 3 & 4 & n.a. \\
\hline Leiria & $>28(28+0)$ & 3 & 5 & 40 \\
\hline Guimarães & $>20(20+?)$ & 7 & 3 & $40^{e}$ \\
\hline Braga & I6 $(\mathrm{I} 6+0)$ & $4^{d}$ & 5 & n.a. \\
\hline Guarda & IO $(10+0)$ & 5 & 8 & n.a. \\
\hline Silves & II $($ IO +0$)$ & $2^{d}$ & I & n.a. \\
\hline
\end{tabular}

${ }^{a}$ When no estimate existed, we used the area coefficients applied by Oliveira Marques (I60 hab./ $\mathrm{km}^{2}$ ) (Marques I98I). ${ }^{\mathrm{b}}$ Sources published in Marques (I980).

${ }^{\mathrm{c}}$ c. I200, Gomes (1998).

${ }^{\mathrm{d}}$ The episcopal notaries of Porto (four) (Silva 20Io, p. 329) and Braga (two) (Marques et al. I990, p. I I) were included. ${ }^{\mathrm{e}}$ Before $\mathrm{I} 348$ (Ferreira I988).

Table A7. Individual yearly allowances in kind (1318-65)

\begin{tabular}{|c|c|c|c|c|}
\hline & \multicolumn{2}{|l|}{ Rural } & \multicolumn{2}{|l|}{ Urban } \\
\hline & $\begin{array}{l}\text { I349 Gulfar } \\
\text { male pobre } \\
\text { vergonçoso }\end{array}$ & $\begin{array}{l}\text { I365 Grijó } \\
45 \text { male and female } \\
\text { workers (p.c.) }\end{array}$ & $\begin{array}{l}\text { I3I } 8 \text { Vila do } \\
\text { Conde } \\
\text { Poor Clares }\end{array}$ & $\begin{array}{l}\text { I328 Coimbra } \\
8 \text { male and } 8 \text { female } \\
\text { pobres vergonçosos }\end{array}$ \\
\hline Grain (liter) & 471.6 & 278.3 & 386 & 515 \\
\hline Wine (liter) & I99.9 & I39.3 & 467 & 467 \\
\hline Meat $(\mathrm{kg})$ & 100.4 & (4 libras) & 0 & 200 \\
\hline Whiting (units) & $2 \mathrm{I} .5$ & & 730 & 87 \\
\hline
\end{tabular}

